\title{
DIGITAL PAYMENT: PROBABILITY IN MILLENIAL (CASE STUDY OF UINSU FEBI STUDENTS)
}

\author{
Muhammad Lathief Ilhamy Nasution ${ }^{a *}$ \\ a) Universitas Islam Negeri Sumatera Utara, Medan, Indonesia \\ ${ }^{*}$ Corresponding Author: mlathiefilhamy@uinsu.ac.id
}

Article history: received 13 July 2020; revised 20 July 2020; accepted 30 July 2020

\begin{abstract}
The rapid technological advances with a very strong internet penetration make the Indonesian people connect to communicate instantly. This has indirectly changed the pattern of human life, especially in the activities of shopping, communicating and working and transacting money in order to spend their income. Therefore with the activities carried out the hope of access to financial services that are affordable, fast and easy to personally connect with various activities. Someone in the internet world makes demands that need to be addressed by modern financial service providers. Internet access has shown a significant increase. This is consistent with the publication of the Association of Internet Service Providers (APJII) in March 2015 stating an increase in internet users, namely from 71.9 million in 2013 to 88.1 million users at the end of 2014 , or about $34.9 \%$ of the total population currently. This digital payment research shows that there is an increase in the quality of banking services in Indonesia. This is because the banking management has implemented it to reach all levels of Indonesian society, especially for millennials living in the FOR (frontier, outermost, and remote) areas..
\end{abstract}

Keywords: probability; digital payment; millenial

\section{INTRODUCTION}

The development of the digital industry in Indonesia continues to increase. As a result of this increase, it has led to innovations in the field of digital payments. Among other things, such as electronic money, digital wallet, and so on. The increase in digital transactions also occurred in a number of countries, including Japan, Singapore, Canada, the United Kingdom, South Korea, Malaysia and the Philippines [1].

At present the people of Indonesia, especially in the downtown area are getting used to non-cash transactions. Daily Social Survey data related to E-money in Indonesia in 2017 shows, of 1055 respondents as many as $56.80 \%$ have electronic money for a year or less. The $42.43 \%$ of respondents felt electronic money helped control spending [2]. Various payment needs are now easier to do thanks to digital payment. However, variations in digital payments in Indonesia continue to develop over time [3].

The era of digital payments began with the issuance of payment cards, for example credit cards and debit cards that can be used as non-cash payment transaction instruments [4]. Better known payment cards to replace cash payments began in the 1980s. Credit and debit cards are the most practical transaction payment media, especially for people who travel abroad. People like the convenience that is facilitated when making transactions therefore encourages banks to offer various advantages and special discounts for their users [5]. In the 2016 period, Bank Indonesia recorded a transaction of $\mathrm{Rp} \mathrm{5,623.91} \mathrm{trillion} \mathrm{in} \mathrm{the} \mathrm{use} \mathrm{of} \mathrm{ATM} \mathrm{/}$ Debit cards. A number of transactions using credit cards in 2016 reached Rp 281 trillion. Also, Bank of Indonesia recorded transactions with electronic money reaching $\mathrm{Rp}$ 7.06 trillion throughout 2016 [6].

Payment card transactions have begun to develop since the advent of $\mathrm{m}$-banking and e-banking in Indonesia. Starting from the Bank Central Asia (BCA) which introduced e-banking massively through the Klik BCA website in 2001. Because of its ease, m-banking and ebanking began to be the choice of people in conducting payment transactions, especially for online shopping at ecommerce platform. As one of the well-known banks in Indonesia, Bank Negara Indonesia (BNI) noted the development of e-banking transactions in 2016 grew rapidly compared to previous years. The development was more by internet banking transactions which jumped $50 \%$. Then the development of SMS or mobile banking transactions grew 40\%, and BNI TapCash also grew 40\% [6].

Digital payments are a method of payment made through digital mode (Dorothy Sagayarani [7]). In payment transactions, payers and recipients use digital mode to send and receive money. All digital payment transactions are done online. The National Digital Research Center (NDRC) defines financial technology as an innovation in the field of financial services. The term comes from the words "financial" and "technology" (FinTech) which refers to financial innovation with a touch of modern technology (Sukma [8]). The development of technology that continues to increase changes many aspects of human daily activity, especially millennial generation. As a generation greatly influenced by technology, their habits are shaped by sophisticated technology, such as smartphones and the internet [9]. One of them is the habit of shopping. Now, millennials are more interested in faster, safer and more convenient payment methods. While cash transactions are 
becoming obsolete, millennials are turning to non-cash or cashless transactions. With this trend, they don't have to carry a lot of money when traveling [10]. The following are some of the payment methods currently popular among millennials. Technological advances that continue to evolve have changed many things in human life, especially in millennial generation. As a generation strongly influenced by technology, their habits are shaped by sophisticated technology, such as smartphones and the internet. One of them is shopping habits. Now, millennials are more interested in faster, safer and more convenient payment methods. While cash transactions are becoming obsolete, millennials are turning to non-cash or cashless transactions. With a trend like this, they don't have to carry a lot of money when traveling. The following are some of the payment methods currently popular among millennials.

The term millennials generally refers to the generation of people born between the early 1980s and 1990s, according to the Merriam - Webster Dictionary. Experts and researchers usually use the early 1980 s as the beginning of the birth of this group and the mid-1990s until the early 2000s as the end of birth.

Millennial nature differs according to region and socio-economic conditions. Nevertheless, this generation can usually be identified by increasing usage and familiarity with communication, media and digital technology. Although their influence is still debated, they are marked by increased political and economic liberalization. The Great Recession is very influential in this generation, which results in high unemployment among young people, and raises speculation about the possibility of a long-term socio-economic crisis that is damaging this generation.

Campus as a gathering place for millennials, one of them is the State Islamic University of North Sumatera (UINSU) campus. In this case study research, the researcher made the Faculty of Islamic Economics and Business of UINSU as the object of research. Where the majority of this faculty students have widely used digital payment facilities in everyday transactions. Can be seen from the initial preresearch interview, researchers have interviewed ten Faculty of Islamic Economics and Business of UINSU students who actively use digital payment transactions, including: OVO, Go Pay from Go-Jek and Paytren. Proven in their ,mobile phone installed the application.

\section{RESEARCH METHODS}

Research that has been conducted in the case of digital payment, among others, is titled Technology Conformity Analysis of the Use of Digital Payment in OVO Applications (Yuanita [11]), SWOT Analysis of Implementation of Financial Technology for Quality of Banking Services in Indonesia (Wulanata [12]). From the research that has been carried out mentioned above only focuses on financial technology. While this research focuses on digital payment. This research goals to find out how the probability of digital payment among millennials in this case is Faculty of Islamic Economics and Business of UINSU students.

In this research the method used is descriptive qualitative. This method describes the response to a situation or event, so that it does not explain the causality relationship or test the hypothesis [13] .

This study uses a SWOT analysis, which is a strategic planning method used to evaluate strengths, weaknesses, opportunities and threats both internally and externally as in the following matrix:

\begin{tabular}{|l|c|c|}
\hline \multirow{1}{*}{ SW } & STRENGTH & WEAKNESS \\
\cline { 2 - 3 } OT & $\begin{array}{c}\text { Determine Internal } \\
\text { Strength Factors }\end{array}$ & $\begin{array}{c}\text { Determine External } \\
\text { Weakness Factors }\end{array}$ \\
\hline $\begin{array}{l}\text { OPPORTUNITY } \\
\text { Determine } \\
\text { Opternal } \\
\text { Factors }\end{array}$ & $\begin{array}{c}\text { SO Strategies } \\
\text { Create strategies that } \\
\text { utilize Strengths to take } \\
\text { advantage Opportunities }\end{array}$ & $\begin{array}{c}\text { WO Strategies } \\
\text { Create strategies that } \\
\text { minimize the } \\
\text { Weaknesses to take } \\
\text { THREAT }\end{array}$ \\
$\begin{array}{l}\text { Determine } \\
\text { External } \\
\text { Threat Factors }\end{array}$ & $\begin{array}{c}\text { ST Strategies } \\
\text { Create strategies that } \\
\text { utilize the Strengths to } \\
\text { take overcome Threats }\end{array}$ & $\begin{array}{c}\text { WT Strategies } \\
\text { Create strategies that } \\
\text { minimize the }\end{array}$ \\
& & $\begin{array}{c}\text { Weaknesses to avoid } \\
\text { Threats }\end{array}$ \\
\hline
\end{tabular}

Figure 1. SWOT Strategies Matrix

\section{RESULTS AND DISCUSSION}

\section{A. SWOT Strategies}

According to the matrix above, it can be stated that digital payment has:

a. Internal strengths, namely:

1) Bank Indonesia Regulation concerning the Implementation of Payment Transaction Processing (PBI No. 18/40 / PBI / 2016).

2) The utilize of digital technology among Faculty of Islamic Economics and Business of UINSU students is very large and has changed the behavior of students in almost all aspects of life.

3) Easily utilize the access to digital payment banking services in large scales and the convenience of ubiquitous transactions.

4) More efficient operational costs and marketing costs because it is widely known by the general public and Faculty of Islamic Economics and Business of UINSU students in particular including 24-hour service applications.

b. Internal Weakness, i.e.:

1) Public knowledge in general and students of Faculty of Islamic Economics and Business of UINSU in particular about digital payment technology is still relatively low so it does not optimally access banking services.

2) Online crime still often occurs such as cybercrime, burglary and tapping in digital payment transactions.

3) Requires a device or tools in the form of a cellphone that can access the internet network. 
4) Requires internet network connectivity, so Faculty of Islamic Economics and Business of UINSU students must provide internet data packages or wireless connections.

5) Making Faculty of Islamic Economics and Business of UINSU students consumptive, as evidenced by the many promos or discounts offered by sellers so that they are stimulating to buy even if the items offered are not needed.

c. External opportunities i.e.:

1) Bank of Indonesia and Financial Services Authority (OJK) stipulate regulations and supervision of financial transactions so as to minimize criminality and the concerns of the general public and students of Faculty of Islamic Economics and Business of UINSU Medan in particular in using digital payments.

2) The number of startup companies that have sprung up to compete in the banking world.

3) The presence of Digital Payment will help people who are still unbankable, whose numbers are still large. Society needs more modern banking services, this encourages Islamic banking to prioritize technologybased services. Therefore, Islamic banking can collaborate with Digital Payment in order to facilitate financial services

\section{d. Threats}

Following is a threat analysis on FinTech which will be implemented in Islamic banking institutions in Indonesia :

1) First, if financial technology service providers utilize of increasingly sophisticated technology by without accompanied by an increase in the quality of human resources in Islamic banking, then it can cause imbalances in serving the banking service user community..

2) Secondly, there is a trend of globalization and openness in conducting cross-border transactions, enabling providers of increasingly diverse financial technology services and creating competition in attracting the interest of the public to use banking services.

3) Third, the political situation is less conducive and the tendency of relatively high inflation in Indonesia, causing banking institutions to be more rigorous in in providing loans to customers, so that it will have an impact on the complexity of the Islamic banking bureaucracy and administrative costs charged to the public as collateral are getting higher .

In addition there is a threat that is the threat of cyber crime in Indonesia. If the relationship between technology and financial services is increasingly tight, then the potential for more sophisticated crime threats is also greater (Muclis [14]).

\section{B. SO Strategy}

Digital Payment strength:

a. Improve Payment Security

E-banking sites are needed to utilize very severe security standards to guarantee that every service they provide is only used by those in authority. One of the protection techniques that is often used in e-banking is over SSL (Secure Socket Layer) or over the HTTPS (Secure HTTP) protocol.

b. Provides Transaction Security More Than Cash

Digital Payment, such as Internet Banking or Mobile Banking, is a leading financial service product in the transfer of physical money transactions into digital money transactions. This is because transacting using digital payment is safer and more secure because it is equipped with a pin that only you know to access it.

This also prevents the loss of cash because the money sent and received will be added to the balance automatically. Increase Effectiveness and Time Efficiency. Digital Banking develops with the development of customer needs and proactively provides the latest technology to customers to increase effectiveness and save time.

\section{c. Providing Ease of Payment Anywhere}

Digital Payment applications and services through Internet Banking are certainly very helpful. By utilizing the Internet Banking application, any activity related to banking services can be done anywhere without having to go to find the nearest bank or ATM.

\section{d. Product Service Options Can Be Continuously Enhanced}

Existing services on the Internet Banking application have various features provided by banking institutions, such as inter-bank money or fund transfer services, telephone payments, internet, balance checks, PDAMs, cable TV, electricity token purchases and payment for airplane ticket purchases. These services can be improved at any time so as to simplify the transaction process for all your needs.

\section{WO Strategies}

Weakness is a limitation of internal and negative situational factors that can potentially disrupt the stability of the company. The disadvantages of digital payment are:

a. Public knowledge of financial technology is still relatively low so that it does not optimally access banking services.

b. Online crimes still occur, such as cybercrime, burglary, wiretapping in banking financial transactions, etc.

c. Inequality of admission to banking services due to communication technology framework that has not been evenly dispersed throughout Indonesia.

d. An internet connection that still lacks support, both in terms of access speed and a stable SNIT proceeding server in sending financial data transactions.

e. Not all financial technology service providers have licenses to collaborate with banking institutions.

Opportunities are factors that provide benefits for companies that are obtained from the company's external environment to obtain profits. Opportunities in digital payment have enormous potential in this and future globalization era. In recent years, digital payment technology in Indonesia has been explored by many business institutions such as banks and telecommunications providers. All industries have conducted research and development in 
order to provide the easiest way for people to carry out daily financial transactions through their Smartphones, which can be a web base (internet banking) or mobile applications (mobile banking, mobile accounts, T-Cash, etc.).

The government itself supports the use of e-money by making Bank Indonesia Regulation No. 18/17 / PBI / 2016 dated 29 August 2016 concerning the Second Amendment to Bank Indonesia Regulation Number 11/12 / PBI / 2009 concerning Electronic Money. The purpose of making this payment system regulation, one of which is to provide security and comfort for the public to conduct buying and selling transactions so that no one feels disadvantaged. The rules regarding payment systems have been established by Bank Indonesia as the Central Bank which has the authority in this matter. The purpose of implementing a non-cash payment system especially with e-money as a micro payment innovation one of which is to optimize purchasing power and increase public consumption figures. The high number of payment transactions in the community makes Bank Indonesia see this as an opportunity for developments in economic innovation in Indonesia.

\section{ST Strategies}

The following is an analysis of threats to financial technology that will be implemented in banking institutions in Indonesia :

a. The use of increasingly sophisticated technology by financial technology service providers, but without being accompanied by an increase in the quality of banking human resources, makes inequality in serving the banking service user community.

b. The existence of globalization trends and the ease of conducting cross-border transactions, enabling providers of financial technology services to become more diversify and create competition in attracting public interest in using banking services.

The political situation is less conducive and the tendency of relatively high inflation in Indonesia, causing banking institutions to be more accurate in providing loans to customers, so that it will have an impact on the complexity of the banking bureaucracy and administrative costs charged to the public as collateral.

\section{E. WT Strategies}

1. Digital Payment which is widely circulated among the military makes digital payment users tend to be lazy individuals. Because digital payment has facilitated their work in transactions.

2. Because the ease of access made by militants makes them spend $70 \%$ of their income to shop, so loading the MPS ratio decreases and of course it will affect the availability of funds in financial institutions.

3. The long-term effects that must be felt by Indonesia if the millennial generation continues to behave extravagantly will make Indonesia must continue to rely on foreign debt to finance infrastructure development.

4. From the perspective of individuals, the weak culture of saving from an early age will reduce the opportunity of millennials to accumulate wealth, which they should be able to enjoy when they are no longer productive and unable to work anymore.

\section{CONCLUSION}

The digital payment system is far more practical than the cash payment method. Digital payment card users, really understand how this system shortens the payment process. This is because you only use one card that is swiped or taped without having to bother reaching into the bag. After payment, you and the cashier do not have to bother counting change.

Digital payment does not escape the threat of crime. Payments with digital payments involve the risk of hacking, data theft, fraud or fraud. One way to maintain national data security in digital payment practices is the government launching a national payment gateway (GPN). With GPN, all transaction data is processed domestically.

After analyzing the strengths, weaknesses, opportunities and threats (SWOT) on the implementation of financial technology, it can be concluded that financial technology has a good level of effectiveness. Banking management is advised to implement this analysis to improve the quality of banking services in Indonesia, so that it can reach all levels of Indonesian society, especially for people who live in the FOR (Frontier, Outermost, and Remote) areas.

\section{REFERENCES}

[1] Kotler, P., and G. Armstrong. 2008. Prinsip-prinsip Pemasaran [Marketing Principles]. Jakarta: Penerbit Erlangga.

[2] Firmansyah and Widiati. 2016. Maksimalisasi Nilai Perbankan Syariah Melalui Teknologi Pelayanan Nasabah Terkini [Maximizing the value of Islamic banking through the latest customer service technology]. Jurnal Keuangan dan Perbankan 20 (2): pp. 274-281.

[3] Kotler, P. 2002. Manajemen Pemasaran di indonesia: Analisis, Perencanaan, Implementasi dan pengendalian [Marketing Management in Indonesia: Analysis, Planning, Implementation and Control]. Jakarta: Penerbit Salemba Empat.

[4] Hartono, J. 2005. Sistem Informasi Strategik untuk Keunggulan Kompetitif [Strategic Information Systems for Competitive Advantage]. Yogyakarta: Andi Offset.

[5] Kurnia., Supriyadi, and Masjono. 2015. Pengaruh Hubungan Pemanfaatan Aplikasi Core Banking System terhadap Kinerja Individu Karyawan PT. Bank BRI Syariah [The Effect of the Relationship between the Utilization of the Core Banking System Application on the Individual Performance of PT. BRI Syariah Bank]. Jurnal Akuntansi, Keuangan dan Perbankan (Account) 1 (3): pp. 247-254. 
[6] Bank Indonesia. 2016. Layanan Keuangan Digital [Digital Financial Services],

[7] Dorothy Sagayarani, 2017. Digital Payments In India, IOSR Journal of Business and Management, 28-33

[8] Sukma, D. 2016 Fintechfest, mempopulerkan teknologi finansial di Indonesia. Arena LTE.

[9] Tobing, Fathorazzi, and Wulandari. 2016. Model inovasi sistem pemasaran perbankan syariah berbasis floating market untuk penciptaan daya saing. Jurnal Keuangan dan Perbankan 20 (1): pp. 75-83.

[10] Sutojo, S. 1997. Manajemen Terapan Bank, Jakarta: Pustaka Binaman Pressindo.

[11] Yuanita Candra Puspita, 2019. Analisis Kesesuaian Teknologi Penggunaan Digital Payment Pada Aplikasi Ovo. Jurnal Manajemen Informatika. Volume 9Nomor 02 Tahun 2019, 121 -128

[12] Wulanata, Imanuel Adhitya Chrismastianto. 2017 Analisis SWOT Implementasi Tekonologi Finansial terhadap Kualitas Layanan Perbankan di Indonesia. Jurnal Ekonomi dan Bisnis. Volume 20 No. 1, April 2017

[13] Koentjaraningrat. 1990. Metode-metode Penelitian Masyarakat [Community Research Methods]. Jakarta: Gramedia.

[14] Muclis, Ridwan. 2018. Analisa SWOT Financial Technology (Fintech) Pembiayaan Perbankan Syariah Di Indonesia (Studi Kasus 4 Bank Syariah Di Kota Medan).Vol 3.No. 2. Medan. 